\title{
MACROSCOPIC LESIONS ON THE GREY TRIGGERFISH, BALISTES CAPRISCUS (PISCES) ASSOCIATED WITH THE PRESENCE OF THE PEDUNCULATE BARNACLE, CONCHODERMA VIRGATUM (CIRRIPEDIA, THORACICA)
}

\author{
BY

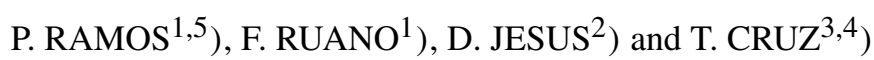 \\ 1) Laboratório de Patologia dos Animais Aquáticos, Instituto Nacional dos Recursos Biológicos, \\ I.P.-IPIMAR, Avenida de Brasília, P-449-006 Lisbon, Portugal \\ 2 ) Associação de Mariscadores da Costa Vicentina e Sudoeste Alentejano Aljezur, Apartado 1008, \\ P-8670-909 Aljezur, Portugal \\ 3 ) Departamento de Biologia \& Laboratório de Ciências do Mar, Universidade de Évora, \\ Apartado 190, P-7520-903 Sines, Portugal \\ $\left.{ }^{4}\right)$ Centro de Oceanografia, Faculdade de Ciências da Universidade de Lisboa, P-1749-016 Lisbon, \\ Portugal
}

\begin{abstract}
Fifteen live specimens of Conchoderma virgatum were attached to a grey triggerfish (Balistes capriscus) caught in S.W. Portugal. The barnacles were distributed in three groups (right abdominal external face, anterior side of the insertion of the pelvic spine, and close to $(5 \mathrm{~mm})$ the left eye (on the lacrymal bone)). The specimens were very different in size, ranging from $2 \mathrm{~mm}$ to $18.9 \mathrm{~mm}$ (maximum capitular length, CL).

The four largest barnacles ( $C L \geqslant 16.4 \mathrm{~mm}$ ) had egg lamellae. Signs of potential predation on the barnacles (rests of barnacles and half-cut cirri in a barnacle) were detected. The left-eye blindness of the grey trigger fish could have been caused by traumatic action performed by the barnacles that settled close to the eye. The skin surrounding the barnacle cluster attached to the right abdominal external face was inflamed. Skin lesions were of sub-acute or chronic nature and the gall-bladder dilatation was consistent with a prolonged status of injury. Both traumatic and inflammatory lesions could have contributed to the loss of body condition of the grey triggerfish. This study is the first report of $C$. virgatum in S.W. Portugal and the first record of attachment to a grey triggerfish.
\end{abstract}

\section{RESUMO}

Foram observados quinze exemplares de Conchoderma virgatum fixos num pampo (Balistes capriscus) capturado na costa SW de Portugal continental. Os cirrípedes encontravam-se distribuídos em três grupos (face abdominal externa direita, face anterior da inserção da barbatana pélvica e

5) e-mail: pramos@ipimar.pt

(C) Koninklijke Brill NV, Leiden, 2010

Crustaceana 83 (9): 1091-1099

Also available online: www.brill.nl/cr

DOI:10.1163/001121610X521163 